\title{
The incentive effects of the Belgian equalization scheme: proposals for reform
}

\author{
Koen Algoed
}

Vives discussion paper 6

July 2009

\section{VIVES}

Naamsestraat 61 bus 3510 3000 Leuven - Belgium

Tel: +32 16324222

www.econ.kuleuven.be/vives 


\section{The incentive effects of the Belgian equalization scheme: proposals for reform}

\section{Introduction}

Equalization transfers from central to sub-central governments are a pervasive feature of nearly all systems of multi-level government. Not surprisingly, in many federal countries such as Canada and Germany, major programs transfer resources from more wealthy jurisdictions to those with relatively small tax bases or tax revenues.

The literature mentions both equity and efficiency reasons for these equalization transfers (see Boadway (2004)). They may be an instrument for achieving horizontal equity among residents of different regions, that is, for ensuring that people can obtain comparable public services at comparable tax rates in all regions. Equalization might also serve as a stabilization device, insuring regions against adverse idiosyncratic shocks with which they may not be able to cope by themselves. Finally, equalization transfers may provide a more "level playing field" for interjurisdictional competition (Oates, 2006).

Equalization schemes may have unintended consequences due to different moral hazard problems (see Boadway (2004)).

First, there is the so-called base tax-back problem. Revenue gains from increasing the tax base will to a greater or lesser extent be offset by losses in equalization. Equalization thus becomes a disincentive where discretion over the tax base is possible. The appropriate remedy would be to offer less than full equalization for revenue sources that can readily be influenced by regional policies.

Next, there is the rate tax-back problem when regional authorities have tax autonomy with respect to tax rates. Take for example the so-called Representative Tax System (RTS) formula where differences in the revenue-raising ability of regions are equalized using a representative tax rate. This representative tax rate can be the average of the tax rates of a representative subset of regions. Equalization transfers enable all regions to raise the same revenues if they applied the representative tax rates to their respective tax bases. A region will have a disincentive to increase rates if its entitlement from that base is negative, and vice versa. If each region is relatively small compared with the nation as a whole, a given region's influence on the national average tax rate will usually be small. In the case of fairly elastic bases, regions will have an incentive to set tax rates too high since the revenue loss from the lower base caused by the high tax rate will be largely offset by increased equalization entitlements. Remark that some of the incentive effects of the equalization system might actually counteract inefficiencies that would otherwise exist in the federal fiscal system (Smart 1998; Bucovetsky and Smart 2002). For example, it is well-known that one of the effects of tax competition is to induce regions into competing down tax rates on inter-regionally mobile tax bases (e.g. capital, goods) to sub-optimal levels. Equalization has a counterbalancing effect.

Finally, if needs differences are equalized along with differences in revenue-raising ability, regions might have an obvious incentive to change their spending policies. Needs equalization is analogous to revenue equalization. The "base" is the number of recipients of a given public service. Regions may be able to influence the number of recipients of particular public programs. They may be less able to influence needs when purely demographic indicators are used. 
The equalization system in Belgium leads, as does any redistributive system, to a trade-off between equity and efficiency objectives. The reduction of the revenue gap of poorer regions by the equalization payment enables them to improve their infrastructure and provide better public services to their population, thus narrowing differences in living standards across the country and meeting equity objectives. At the same time, however, the equalization system provides disincentives to the poorer regions to develop their growth potential as an increase in their tax base reduces the transfers from the federal government, thus levying an implicit tax on economic efforts of the region. Cattoir and Verdonck (2002) found that this implicit tax is above $100 \%$ for Wallonia and Brussels, i.e. if Wallonia or Brussels increase their personal income tax revenues, their overall revenue declines as the increase in the transferred income tax from the federal is outweighed by the reduction in the equalisation transfer. Conversely, if economic performance (as defined by the contribution to the federal personal income tax revenues) weakens in Wallonia and Brussels, the decline in the transfer from the shared income tax is more than offset by the increase in the equalisation transfer

The purpose of this paper is to analyse the incentive effects on subfederal governmental behavior in Belgium of both the current and an alternative financing scheme. We therefore derive the sensitivity of the Regions' budget with respect to a change in the personal income tax base. Cattoir-Verdonck (2002) calculated the budgetary return for the Regions of an increase in (federal) personal tax revenues. The increase is implicitly assumed to be the result of an increase in GDP. In Algoed (2008) the exogenous variable was a change in regional GDP. This enabled to take into account the effect of commuters and the possible spill-over effect of an an increase in regional GDP on the regional taxes.

Section 2 briefly describes the key features of the Belgian financial arrangements for the Regions. In section 3 the incentive effects of the current financing system are discussed. Section 4 discusses the incentive and budgetary effects of a tax sharing financing system for the Regions. Section 5 concludes.

\section{Current financial arrangements for the regions in Belgium}

The main financial transfer to the Regions is the so-called federal personal income tax transfer. It is a grant rather than a shared tax as it is not a fixed proportion of the total revenue from the personal income tax. The federal personal income tax transfer is a vertical lump sum payment, defined in 1989 and tied to the consumer price index and real GDP growth. It is funded from the proceeds of the personal income taxes. Since 1990 the federal personal income tax transfer is horizontally attributed to the Regions according to each Region's contribution to federal personal income tax revenues.

As compensation for the change in the horizontal allocation formula ${ }^{1}$, an equalization grant has been attributed to the Regions. A Region whose per-capita revenues from personal income tax are lower than the national average receives each year a $11.6 €$ indexed transfer per inhabitant per percentage point difference between the per-capita revenues from personal income tax and the national average.

Finally, each Region obtains a closed-ended grant from the federal budget as a compensation for each unemployed for whom the Region creates a job. This grant is indexed neither to the consumer price index nor to GDP, but has been increased several times.

1 Before 1990 the horizontal shares were defined in light of three identically weighted criteria, i.e. population, revenues generated by personal income tax and surface area (the so-called "three-thirds" rule). 
Next to the federal financial transfers, regional taxes represent the Regions' other major financing resource ${ }^{2}$.

The Regions exercise their fiscal powers in three ways.

First, the Finance Act stipulates a list of taxes that used to be federal revenues and have been transferred to the Regions. The Regions now have full fiscal autonomy (i.e. disposal of the revenues, determination of the tax base and the rates) with respect to 12 taxes $^{3}$. The taxes concerned are 1) the tax on gambling and betting 2) the tax on automatic amusement devices 3) taxes on alcohol licences 4) the estate tax and inheritance tax 5) radio and television licence fees 6) the real estate tax 7) registration fees on real estate transfers 8 ) mortgage registration fees 9) duties on gifts 10) road fund tax on automobiles 11) vehicle registration fees and 12) Eurovignette.

Secondly, the Regions also have the possibility of creating additional taxes or granting rebates on the portion of personal income tax attributed to them. This 'piggyback' personal income tax now amounts to maximum $6,75 \%$ of personal income tax localized in each region.

Finally, the Regions have their own tax-raising powers in respect of matters that are not already taxed by another authority.

\section{Incentive effects of the current system (base tax-back problem)}

The federal income tax revenues are used to determine both the horizontal allocation of the federal grant across regions and the solidarity payment. The federal government has discretion over the tax rates and the tax bases (for example through tax deductions. Regions too have discretion over the personal income tax base (and hence the federal income tax revenues) as they are responsible inter alia for active labour market policies and economic policy. As the regional tax autonomy with respect to tax rates and exemptions is not relevant here, we only have to take into account the possible base tax-back problem, not the rate tax-back problem. Cattoir and Verdonck (2002) have shown that the Belgian equalization mechanism leads to a base tax-back problem (they called it poverty trap) for the regions benefiting from equalization. They assumed the increase in personal income tax revenues to be the result of an increase in the regional GDP, here we look at the budgetary effect of a change in the regional personal income tax base.

\footnotetext{
${ }^{2}$ Regions also benefit from non-tax revenues and the eventual proceeds of borrowing.

${ }^{3}$ The state reform of 2001 increased the tax autonomy of the Regions while maintaining vertical budgetary neutrality. Given the transfers of revenues from the new regional taxes, there is a reduction in the personal income tax transfer granted to the regions, i.e. the so-called negative term. The negative term of each region has been defined as the average of revenues from newly transferred taxes collected in 1999, 2000 and 2001 (the averages were expressed in 2002 prices). Subsequently, the negative terms have been linked to inflation plus $91 \%$ of real GDP growth. The radio-TV licence fees became in 2002 a regional instead of a community tax. They are also a part of the negative term but they are only linked to inflation. The radio-TV licence fees reduce the federal personal income tax transfer to the regions but these savings have been transmitted to the Communities.
} 
We introduce the following notation in order to describe formally the budgetary revenues for Region $i$ in year $t$ :

$Y_{t}^{i}=$ the personal income tax base of Region $\mathrm{i}$ in year $t$,

$P I T_{t}^{i}=$ the personal income tax revenues of Region $\mathrm{i}$ in year $t$,

$P I T_{t}=$ the personal income tax revenues of Belgium as a whole in year $t$,

$X_{t}=$ federal grant in year $\mathrm{t}$,

$\pi_{t}=$ the rate of inflation in year $t$,

$P O P_{t}^{i}=$ the number of residents in Region i in year $t$,

$P O P_{t}=$ total population in year $t$

$R T_{t}^{i}=$ the proceeds from regional taxes in Region $\mathrm{i}$ in year $t$

The budgetary revenues for Region i in year $t, R E V_{t}^{i}$, are equal to

$R E V_{t}^{i}=R T_{t}^{i}+X_{t} \cdot\left(\frac{P I T_{t}^{i}}{P I T_{t}}\right)+\sigma_{t}^{i} \cdot 100 \cdot\left[1-\frac{P I T_{t}^{i} / P O P_{t}^{i}}{P I T_{t} / P O P_{t}}\right] \times P_{t}{ }_{t}^{i}$

with

$\sigma_{t}^{i}=11,6 \cdot \prod_{\xi=1989}^{t}\left(1+\pi_{\xi}\right)$ when $\left[1-\frac{P I T_{t}{ }^{i} / P O P_{t}{ }^{i}}{P I T_{t} / P O P_{t}}\right]>0$, zero otherwise

The budgetary impact of a change in the personal income tax base in region i for the regional authority $i$ is given by:

$$
\frac{\partial R E V_{t}^{i}}{\partial Y_{t}^{i}}=\left(X_{t}-\sigma_{t}^{i} \cdot P O P_{t}^{t o t} \cdot 100\right) \cdot\left(\frac{\sum_{j} P I T_{t}^{j}-P I T_{t}^{i}}{\left(\sum_{j} P I T_{t}^{j}\right)^{2}}\right) \cdot \frac{\partial P I T_{t}^{i}}{\partial Y_{t}^{i}}
$$


The own marginal revenue is determined positively by the elasticity of the tax revenues with respect to the personal income tax base and negatively by the own regional share in the federal personal income tax revenues.

The spillover effect of a change in the personal income tax base in region $\mathrm{i}$ on the budget of regional authority $\mathrm{k}$ is given by

$$
\frac{\partial R E V_{t}^{k}}{\partial Y_{t}^{i}}=\frac{\left(\sigma_{t}^{k} \cdot P O P_{t}^{t o t} \cdot 100-X_{t}\right) \cdot P I T_{t}^{k}}{\left(\sum_{j} P I T_{t}^{j}\right)^{2}} \cdot \frac{\partial P I T_{t}^{i}}{\partial Y_{t}^{i}}
$$

The spillover effect depends positively on the share of region $\mathrm{k}$ in the federal personal income tax revenues.

Using those derivatives and the estimated personal income tax revenue function (see below), Table 1 shows the effect of a marginal increase in the personal income tax base of one region on its own budget, on the budget of the other regions and on the federal budget.

The personal income tax revenue function taking into account the different marginal tax rates, can be approximated by the following function: $P I T_{t}^{i}=Y_{t}^{i}-3,7 \cdot\left(Y_{t}^{i}\right)^{0,83}$ (see Decoster (2009)). The marginal tax revenue is evaluated at the average regional taxable income.

The increase in tax revenues due to a marginal increase in the tax base varies between $39,46 \%$ (Brussels), 40,3\% (Wallonia), and 42,02 \% (Flanders). These revenues accrue for one $100 \%$ to the federal government. The figures in last column of Table 1 (federal level) indicate revenues (+/-) in addition to the marginal revenues from the personal income tax. Besides changes in the personal income tax revenues, a change in the PIT tax base may induce the payment of social security contributions.

For the regions the change in the personal income tax revenues due to the change in the personal income tax base influences the horizontal allocation formula and possibly the equalization payment.

For the regions enjoying an equalization payment, in casu Brussels and Wallonia, there is a clear base tax-back problem. The negative effect on the solidarity payment of the increase in the tax base crowds out the positive budgetary effect on the horizontal allocation formula.

For example a marginal increase of the personal income tax base in Wallonia, say one euro, increases the grant with 8 eurocent but reduces the equalization payment with 17,53 eurocent. The gain in the grant for Wallonia is at the expense of the other regions (zero-sum game). Brussels benefits from a 
higher equalization payment as the difference with the national average increases due to the increase in per capita tax revenues in Wallonia : $+1,99$ eurocent. The net savings on the equalization payments are positive for the federal government, in this case 15,53 eurocent. Adding up the marginal change in personal income tax revenues, 40,3 eurocent, the total budgetary gain (apart from the increase in social security contributions) for the federal government equals 55,83 eurocent.

Table 1. Budgetary effects of a marginal increase in the regional PIT tax base with the present, vertical, equalization mechanism (in eurocent ; increase in regional PIT tax base=1 euro)

\begin{tabular}{|c|c|c|c|c|}
\hline 2006 & Walloon region & Flemish region & Brussels region & $\begin{array}{c}\text { Federal } \\
\text { Level }\end{array}$ \\
\hline $\begin{array}{l}\text { Effect of } \Delta \text { PIT base in the Walloon region } \\
\text { on total revenues: } \\
\text { - from which equalization effect } \\
\text { - from which PIT transfer effect }\end{array}$ & $\begin{array}{c}-9.53 \\
-17,53 \\
8.0\end{array}$ & $\begin{array}{c}-7.09 \\
0,0 \\
-7.09\end{array}$ & $\begin{array}{l}1,08 \\
1,99 \\
-0,91\end{array}$ & $\begin{array}{c}15,53 \\
15.53 \\
0,0\end{array}$ \\
\hline $\begin{array}{l}\text { Effect of } \Delta \text { PIT base in the Flemish region } \\
\text { on total revenues: } \\
\text { - from which equalization effect } \\
\text { - from which PIT transfer effect }\end{array}$ & $\begin{array}{l}3.82 \\
7,02 \\
-3,21\end{array}$ & $\begin{array}{l}4,15 \\
0,0 \\
4,15\end{array}$ & $\begin{array}{l}1,13 \\
2,08 \\
-0,95\end{array}$ & $\begin{array}{l}-9,1 \\
-9,1 \\
0,0\end{array}$ \\
\hline $\begin{array}{l}\text { Effect of } \Delta \text { PIT base in the Brussels region } \\
\text { on total revenues: } \\
\text { - from which equalization effect } \\
\text { - from which PIT transfer effect }\end{array}$ & $\begin{array}{l}3.59 \\
6.60 \\
-3,01\end{array}$ & $\begin{array}{c}-6,94 \\
0,0 \\
-6,94\end{array}$ & $\begin{array}{c}-11.85 \\
-21.80 \\
9,95\end{array}$ & $\begin{array}{c}15.21 \\
15.21 \\
0,0\end{array}$ \\
\hline
\end{tabular}

Source: own calculations

Any measure of economic policy leading to an increase of the income of a region benefiting from the equalization system, is penalized by a reduction of the financial means of the government. The explanation of this poverty trap phenomenon is clear from the break down of the total effect of an increase in PIT revenues in, on the one hand, the PIT transfer effect and, on the other hand, the equalization effect. The PIT transfer effect is the increase of the share of the federal PIT block grant following the relative increase in PIT revenues in a region. The equalization effect is the decrease of equalization transfer following the relative improvement of wealth in that region. This second effect is nil for regions with PIT revenue per capita higher than the national average. One can see that the 
equalization effect overcompensates the PIT transfer effect, and that is the origin of the disincentive character of the Belgian financial arrangements for the regions.

\section{A new financing scheme for the regions}

In order to cancel the disincentive effect of the current financing scheme, a new financing system for the regions should insure that when PIT revenues increase in a region, the PIT transfer effect is not crowded out by the equalization effect. This can be accomplished both by transforming the PIT grant in a real shared tax mechanism and the introduction of an equalization system based upon tax capacities.

A first alternative equalization mechanism reduces, as is the case in Canada, the gap between regional per capita PIT revenue and the national average in the same proportion for all the regions benefiting from equalization transfers but does not change the ranking of the below average regions. A second alternative brings all the relatively poor regions to the same level compared to the national average. Their relative positions are then equalized. In Germany for example the financial capacity of the Länder is raised to at least $91 \%$ of the national average.

Besides the choice of the benchmark in the equalization scheme, one also has to decide if regional populations will be weighted or not in calculating the per capita tax revenues or tax bases. Though debates are lively about the question, many papers have shown the specific needs and subsequent costs borne by the capital city-region. In Germany, the population of the city-states of Hamburg, Berlin and Bremen is taken into account at $135 \%$ in the equalization formulas in order to grant additional financial means to these Länder to cover their above average costs. As the proposed equalization formula includes population parameters, it is possible to adopt the German technique.

Finally, equalization consists of a system of unconditional redistributive transfers among governments, and can take two broad forms. A gross scheme involves transfers from the central government to the regions financed from central tax revenues, while a net scheme consists of self-financing region-toregion transfers. In principle, net and gross schemes are equivalent from an equalization perspective: a gross scheme can replicate the equalizing outcome of a net scheme, but to do so it requires a larger share of tax room at the central level relative to its own expenditure requirements, that is, a larger vertical fiscal gap. The incentive effects may also differ.

\subsection{New financing system: Canadian type, shared taxes}

If a shared tax and a Canadian alike equalization scheme replace the present financing mechanism, the regional revenues can be expressed by the following formula: 


$$
\begin{aligned}
R E V_{i}^{t} & =R T_{i}^{t}+\gamma \cdot P I T_{t}^{t}\left(\frac{P I T_{t}^{i}}{P I T_{t o t}^{t}}\right)+\alpha \cdot \gamma \cdot\left[\frac{P I T_{t}}{\sum_{j=1}^{N} \omega_{j} P O P_{t}^{j}}-\frac{P I T_{t}^{i}}{\omega_{i} P O P_{t}^{i}}\right] \times \omega_{i} P O P_{t}^{i} \\
& =R T_{i}^{t}+(1-\alpha) \cdot \gamma \cdot P I T_{t}^{t}+\alpha \cdot \gamma \cdot P I T_{t} \cdot \frac{\omega_{i} P O P_{t}^{i}}{\sum_{j=1}^{N} \omega_{j} P O P_{t}^{j}}
\end{aligned}
$$

where $\gamma \in[0,1]$ is the share of PIT revenues assigned to the regions and $\omega_{i}$ is the weight given to population in Region $\mathrm{i}$.

The proposed scheme only considers personal income tax revenues. A percentage, $\gamma$, of the personal income taxes perceived in region i accrues to region $\mathrm{i}$. There is also an incoming or outgoing fiscal flow depending on the deviation of the per capita regional tax revenues from the national per capita tax revenues. $\alpha$, being a policy parameter, determines to what extent the per capita regional tax revenues are allowed to deviate from the national per capita tax revenues. For $\alpha=1$ every region is, besides the own tax revenues, entitled to the national per capita tax revenues times the own population.

To be coherent, the reform should consider all regional fiscal revenue sources in the equalization formula. Indeed, the Brussels region faces higher costs linked to its central position but gets also some fiscal benefits through the form of higher yields in regional taxes. Such a broader equalization formula, including revenues from regional taxes, would then take into account the benefits as well as the costs of the city-state. But one difficulty associated with this proposal is that while the personal income tax is defined at the federal level and is therefore uniform on the whole territory, the regional taxes are mainly defined at the regional level and, as a consequence, tax legislations may vary significantly across the regions. Moreover, some regional taxes are lump-sum, others have non comparable tax bases. This complicates the implementation of a representative tax system as in Canada where average tax rates and theoretical tax bases are calculated.

In a horizontal equalization scheme the fiscal flows between regions add up to zero. Or:

$$
\sum_{i=1}^{N} \alpha \cdot \gamma \cdot\left[\frac{P I T_{t}^{t o t}}{\sum_{j=1}^{N} \omega_{j} P O P_{t}^{j}}-\frac{P I T_{t}^{i}}{\omega_{i} P O P_{t}^{i}}\right] \times \omega_{i} P O P_{t}^{i}=0
$$

For given $\alpha$ and $\gamma$ the incentive effects of the proposed scheme are as follows: 


$$
\begin{aligned}
& \frac{\partial R E V_{t}^{i}}{\partial Y_{t}^{i}}=\gamma \cdot\left(1-\alpha \cdot\left(1-\frac{\omega_{i} P O P_{t}^{i}}{\sum_{j=1}^{N} \omega_{j} P O P_{t}^{j}}\right)\right) \cdot \frac{\partial P I T_{t}^{i}}{\partial Y_{t}^{i}} \\
& \frac{\partial R E V_{t}^{k}}{\partial Y_{t}^{i}}=\frac{\partial P I T_{t}^{i}}{\partial Y_{t}^{i}} \cdot \gamma \cdot \alpha \cdot \frac{\omega_{k} P O P_{t}^{k}}{\sum_{j=1}^{N} \omega_{j} P O P_{t}^{j}} \\
& \text { with } \sum_{k=1}^{N} \frac{\partial R E V_{t}^{k}}{\partial Y_{t}^{i}}=\frac{\partial P I T_{t}^{i}}{\partial Y_{t}^{i}} \cdot \gamma
\end{aligned}
$$

There is no negative base tax-back effect. The own marginal budgetary return of a change in the tax base is positively related to $\gamma$ but negatively to $\alpha$.

The incentive effect is positive except for $\alpha=1$ and $\frac{\omega_{i} P O P_{t}^{i}}{\sum_{j=1}^{N} \omega_{j} P O P_{t}^{j}}=0$. The latter happens in the case of a small region.

The cross-border marginal budgetary return is positively related both to $\gamma$ and $\alpha$ (in a setting where the change in tax base could be due to changes in tax rates, the equalization scheme offers protection against tax competition).

As the central government owns 1- $\gamma$ of the personal income tax revenues, the marginal budgetary return for central government equals

$$
(1-\gamma) \cdot \frac{\partial P I T_{t}^{i}}{\partial Y_{t}^{i}}
$$

Contrary to the current scheme (see Table 1) there are no other budgetary returns for the federal government when an economic lagging region improves its relative fiscal position.

Table 2 describes the incentive effects for $\gamma=0,31, \alpha=0,4 ; \omega=1$ for a horizontal equalization scheme. Between brackets are the results when a weight of 1,35 is given to the Brussels' population. 
For every region the change in the personal income tax revenues dominates the change in the equalization effect when the own PIT tax base changes. Hence the change in budgetary revenues is positively related to the change in personal income tax base.

The cross-border budgetary effect is also positive.

Table 2. Budgetary effects of a marginal increase in the regional PIT tax base with the new horizontal equalization mechanism (in eurocent ; increase in regional PIT tax base=1 euro)

\begin{tabular}{|c|c|c|c|c|}
\hline 2006 & Walloon region & Flemish region & Brussels region & $\begin{array}{c}\text { Federal } \\
\text { Level }\end{array}$ \\
\hline $\begin{array}{l}\text { Effect of } \Delta \text { PIT base in the Walloon region } \\
\text { on total revenues: } \\
\text { - from which equalization effect } \\
\text { - from which PIT effect }\end{array}$ & $\begin{array}{c}9.13(9.08) \\
-3.38(-3.43) \\
12.51\end{array}$ & $\begin{array}{c}2,89(2.80) \\
2,89(2.80) \\
0,0\end{array}$ & $\begin{array}{c}0,48(0.63) \\
0,48(0.63) \\
0,0\end{array}$ & $\begin{array}{c}-12.51 \\
0,0 \\
-12.51\end{array}$ \\
\hline $\begin{array}{l}\text { Effect of } \Delta \text { PIT base in the Flemish region } \\
\text { on total revenues: } \\
\text { - from which equalization effect } \\
\text { - from which PIT effect }\end{array}$ & $\begin{array}{c}1,69(1.64) \\
1,69(1.64) \\
0,0\end{array}$ & $\begin{array}{c}10.84(10.74) \\
-2.20(-2.30) \\
13.04\end{array}$ & $\begin{array}{c}0,50(0.66) \\
0,50(0.66) \\
0,0\end{array}$ & $\begin{array}{c}-13.04 \\
0,0 \\
-13.04\end{array}$ \\
\hline $\begin{array}{l}\text { Effect of } \Delta \text { PIT base in the Brussels region } \\
\text { on total revenues: } \\
\text { - from which equalization effect } \\
\text { - from which PIT effect }\end{array}$ & $\begin{array}{c}1,59(1.54) \\
1,59(1.54) \\
0,0\end{array}$ & $\begin{array}{c}2,83(2.74) \\
2,83(2.74) \\
0,0\end{array}$ & $\begin{array}{c}7.82(7.97) \\
-4.43(-4.28) \\
12.25\end{array}$ & $\begin{array}{c}-12.25 \\
0,0 \\
-12.25\end{array}$ \\
\hline
\end{tabular}

Source: own calculations

Remark: column federal level indicates revenues (+/-) in addition to the revenues from the personal income tax

The parameters $\alpha, \gamma$ and $\omega$ determine not only the magnitude of the incentive effects but also the distributional effects. Table 3 describes using a static approach the budgetary means under the current and the new financing scheme. The value for $\gamma$ is given by the current federal grant to the regions divided by the personal income tax revenues (figures 2006). $\alpha$ is set at $40 \%$. 
From a static point of view and given the value of $\gamma$ the results are budgetary neutral for the federal government. The consequence is that budgetary gains for one region entail losses for another region. The value of $\alpha$ determines the size of the gain/loss for a given $\gamma$.

Table 3. Revenues (in euro): new $(\gamma=0,31 ; \alpha=0,4)$ versus current system (figures 2006)

\begin{tabular}{|l|r|r|r|r|r|}
\hline & Shared taxes & Solidarity payment & \multicolumn{1}{l|}{$\begin{array}{l}\text { Total revenues } \\
\text { new system }\end{array}$} & \multicolumn{1}{l}{$\begin{array}{l}\text { Current } \\
\text { system }\end{array}$} & \multicolumn{1}{l|}{ Difference } \\
\hline Flanders & 5.747 .184 .601 & -714.573 .814 & 5.032 .610 .786 & 5.113 .584 .644 & -80.973 .858 \\
\hline Wallonia & 2.492 .829 .684 & 547.015 .933 & 3.039 .845 .616 & 3.148 .167 .223 & -108.321 .607 \\
\hline Brussels & 737.705 .968 & 167.557 .882 & 905.263 .849 & 715.968 .385 & 189.295 .465 \\
\hline
\end{tabular}

Source: own calculations

Table 4. Revenues (in euro): new ( $\gamma=0,31 ; \alpha=0,4 ; \omega$ Brussels=1,35) versus current system (figures 2006)

\begin{tabular}{|l|r|r|r|r|r|}
\hline & \multicolumn{1}{|l|}{ Shared taxes } & \multicolumn{1}{l|}{$\begin{array}{l}\text { Solidarity } \\
\text { payment }\end{array}$} & \multicolumn{1}{l|}{$\begin{array}{l}\text { Total revenues } \\
\text { new system }\end{array}$} & \multicolumn{1}{l}{$\begin{array}{l}\text { Current } \\
\text { system }\end{array}$} & \multicolumn{1}{l|}{ Difference } \\
\hline Flanders & 5.747 .184 .601 & -933.565 .577 & 4.813 .619 .024 & 5.113 .584 .644 & -299.965 .620 \\
\hline Wallonia & 2.492 .829 .684 & 423.987 .902 & 2.916 .817 .586 & 3.148 .167 .223 & -231.349 .638 \\
\hline Brussels & 737.705 .968 & 509.577 .675 & 1.247 .283 .642 & 715.968 .385 & 531.315 .258 \\
\hline
\end{tabular}

Source: own calculations

\subsection{New system: German type, shared taxes}

As a variant to the equalization scheme proposed in section 4.1, the equalization payments entitle every region to a minimum of $\beta$ percent of the national per capita tax revenues.

In a horizontal equalization scheme the budgetary revenues for a recipient region $\mathrm{i}$ are equal to 


$$
\begin{aligned}
R E V_{i}^{t} & =R T_{i}^{t}+\gamma \cdot P I T_{t}^{\text {tot }}\left(\frac{P I T_{t}^{i}}{P I T_{t}^{\text {tot }}}\right)+\gamma \cdot\left[\frac{\beta \cdot P I T_{t}}{\sum_{i} \omega_{i} P O P_{t}^{i}}-\frac{P I T_{t}^{i}}{\omega_{i} P O P_{t}^{i}}\right] \times \omega_{i} P O P_{t}^{i} \\
& =R T_{i}^{t}+\gamma \cdot \beta \cdot P I T_{t} \cdot \frac{\omega_{i} P O P_{t}^{i}}{\sum_{i} \omega_{i} P O P_{t}^{i}}
\end{aligned}
$$

A recipient region being defined by

$$
\frac{\beta \cdot P I T_{t o t}^{t}}{\sum_{i} \omega_{i} P O P_{i}^{t}}>\frac{P I T_{i}^{t}}{\omega_{i} P O P_{i}^{t}}
$$

whereas for a donor region the budgetary revenues are equal to

$$
R E V_{i}^{t}=R T_{i}^{t}+\gamma \cdot P I T_{\text {tot }}^{t}\left(\frac{P I T_{i}^{t}}{P I T_{\text {tot }}^{t}}\right)-\psi_{i} \sum_{k} \gamma \cdot\left[\frac{\beta \cdot P I T_{t o t}^{t}}{\sum_{j} \omega_{j} P O P_{j}^{t}}-\frac{P I T_{k}^{t}}{\omega_{k} P O P_{k}^{t}}\right] \times \omega_{k} P O P_{k}^{t}
$$

where $\mathrm{k}$ denotes a recipient region

The condition for being a donor region is $\frac{\beta \cdot P I T_{t o t}^{t}}{\sum_{i} \omega_{i} P O P_{i}^{t}}<\frac{P I T_{i}^{t}}{\omega_{i} P O P_{i}^{t}}$

$\psi_{i}$ is the share of donor region $\mathrm{i}$ in the equalization transfers. This share could be determined as follows

$$
\psi_{i}=\frac{\left(\frac{P I T_{i}^{t}}{P O P_{i}^{t}}-\beta \frac{P I T^{t}}{P O P^{t}}\right) \cdot \frac{P O P_{i}^{t}}{P O P^{t}}}{\sum_{k^{\prime}}\left(\frac{P I T_{k^{\prime}}^{t}}{P O P_{k^{\prime}}^{t}}-\beta \frac{P I T^{t}}{P O P^{t}}\right) \cdot \frac{P O P_{k^{\prime}}^{t}}{P O P^{t}}}
$$

We determine the effects of a marginal increase in the PIT tax base of respectively a recipient and donor region. We thereby assume that the marginal change in PIT base doesn't change the status (donor/recipient) of the region.

\subsubsection{Recipient region}

In the case of a recipient region the own budgetary effect equals 


$$
\frac{\partial R E V_{t}^{i}}{\partial Y_{t}^{i}}=\frac{\partial P I T_{t}^{i}}{\partial Y_{t}^{i}} \cdot \gamma \cdot \beta \cdot \frac{\omega_{i} P O P_{t}^{i}}{\sum_{j} \omega_{j} P O P_{t}^{j}}
$$

whereas the cross-border budgetary effects are respectively

$$
\begin{aligned}
& \frac{\partial R E V_{t}^{k}}{\partial Y_{t}^{i}}=\frac{\partial P I T_{t}^{i}}{\partial Y_{t}^{i}} \cdot \gamma \cdot \beta \cdot \frac{\omega_{k} P O P_{t}^{k}}{\sum_{j} \omega_{j} P O P_{t}^{j}} \text { for another recipient region } \mathrm{k} \\
& \frac{\partial R E V_{t}^{k^{\prime}}}{\partial Y_{t}^{i}}=-\psi_{k^{\prime}} \cdot \gamma \cdot \frac{\partial P I T_{t}^{i}}{\partial Y_{t}^{i}} \cdot \beta \cdot \frac{\sum_{k} \omega_{k} P O P_{k}^{t}}{\sum_{j} \omega_{j} P O P_{j}^{t}} \text { for a donor region } \mathrm{k}^{\prime}
\end{aligned}
$$

A change in the tax base of a recipient region involves a zero-sum budgetary game since

$$
\begin{aligned}
& \sum_{k^{\prime}} \frac{\partial R E V_{t}^{k^{\prime}}}{\partial Y_{t}^{i}}+\sum_{k} \frac{\partial R E V_{t}^{k}}{\partial Y_{t}^{i}}=0 \\
& \frac{\partial P I T_{t}^{i}}{\partial Y_{t}^{i}} \text { accrues to the federal government. }
\end{aligned}
$$

\subsubsection{Donor region}

A change in the tax base of a donor region has following budgetary effects:

$$
\begin{aligned}
& \frac{\partial R E V_{t}^{i}}{\partial Y_{t}^{i}}=\frac{\partial P I T_{t}^{i}}{\partial Y_{t}^{i}} \cdot \gamma \cdot\left(1-\psi_{i} \cdot \beta \cdot \frac{\sum_{k} \omega_{k} \cdot P O P_{k}^{t}}{\sum_{j} \omega_{j} P O P_{j}^{t}}\right) \\
& \frac{\partial R E V_{t}^{k}}{\partial Y_{t}^{i}}=\frac{\partial P I T_{t}^{i}}{\partial Y_{t}^{i}} \cdot \gamma \cdot \beta \cdot \frac{\omega_{k} P O P_{t}^{k}}{\sum_{j} \omega_{j} P O P_{t}^{j}} \text { for a recipient region } \mathrm{k} \\
& \frac{\partial R E V_{t}^{k^{\prime}}}{\partial Y_{t}^{i}}=-\psi_{k^{\prime}} \cdot \beta \cdot \gamma \cdot \frac{\partial P I T_{t}^{i}}{\partial Y_{t}^{i}} \cdot \frac{\sum_{k} \omega_{k} \cdot P O P_{k}^{t}}{\sum_{j} \omega_{j} P O P_{j}^{t}} \text { for another donor region } \mathrm{k}^{\prime}
\end{aligned}
$$

A change in the tax base of a donor region involves a positive-sum budgetary game: 
$\sum_{k^{\prime}} \frac{\partial R E V_{t}^{k^{\prime}}}{\partial Y_{t}^{i}}+\sum_{k} \frac{\partial R E V_{t}^{k}}{\partial Y_{t}^{i}}=\gamma \cdot \frac{\partial P I T_{t}^{i}}{\partial Y_{t}^{i}}$

$(1-\gamma) \cdot \frac{\partial P I T_{t}^{i}}{\partial Y_{t}^{i}}$ accrues to the federal government.

Table 5 describes the incentive effects for $\gamma=0,31, \beta=0,91 ; \omega=1$ in the case of a horizontal equalization scheme. Flanders is the donor region whereas Brussels and Wallonia are recipient regions.

Table 5. Budgetary effects of a marginal increase in the regional PIT tax base with the new horizontal equalization mechanism $(\boldsymbol{\beta}=\mathbf{0 , 9 1 ;} \boldsymbol{\gamma}=\mathbf{0 , 3 1} ; \boldsymbol{\omega = 1}$, in eurocent ; increase in regional PIT tax base=1 euro)

\begin{tabular}{|c|c|c|c|c|}
\hline 2006 & Walloon region & Flemish region & Brussels region & $\begin{array}{c}\text { Federal } \\
\text { Level }\end{array}$ \\
\hline $\begin{array}{l}\text { Effect of } \Delta \text { PIT base in the Walloon region } \\
\text { on total revenues: } \\
\text { - from which equalization effect } \\
\text { - from which PIT effect }\end{array}$ & $\begin{array}{l}3,7 \\
3,7 \\
0,0\end{array}$ & $\begin{array}{l}-4,8 \\
-4,8 \\
0,0\end{array}$ & $\begin{array}{l}1,1 \\
1,1 \\
0,0\end{array}$ & $\begin{array}{l}0,0 \\
0,0 \\
0,0\end{array}$ \\
\hline $\begin{array}{l}\text { Effect of } \Delta \text { PIT base in the Flemish region } \\
\text { on total revenues: } \\
\text { - from which equalization effect } \\
\text { - from which PIT effect }\end{array}$ & $\begin{array}{l}3,86 \\
3,86 \\
0,0\end{array}$ & $\begin{array}{c}8,04 \\
-5,0 \\
13,04\end{array}$ & $\begin{array}{r}1,15 \\
1,15 \\
0,0\end{array}$ & $\begin{array}{c}-13,04 \\
0,0 \\
-13,04\end{array}$ \\
\hline $\begin{array}{l}\text { Effect of } \Delta \text { PIT base in the Brussels region } \\
\text { on total revenues: } \\
\text { - from which equalization effect } \\
\text { - from which PIT effect }\end{array}$ & $\begin{array}{l}3,62 \\
3,62 \\
0,0\end{array}$ & $\begin{array}{l}-4,7 \\
-4,7 \\
0,0\end{array}$ & $\begin{array}{r}1,08 \\
1,08 \\
0,0\end{array}$ & $\begin{array}{l}0,0 \\
0,0\end{array}$ \\
\hline
\end{tabular}

Source: own calculations

Remark: column federal level indicates revenues (+/-) in addition to the revenues from the personal income tax 
Table 6 describes using a static approach the budgetary means under the current and the new financing scheme. The value for $\gamma$ is given by the current federal grant to the regions divided by the personal income tax revenues (figures 2006).

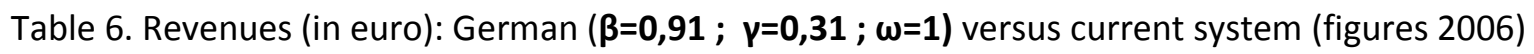

\begin{tabular}{|l|r|r|r|l|l|}
\hline & Shared taxes & Solidarity payment & \multicolumn{1}{l}{ Total revenues } & \multicolumn{1}{l}{$\begin{array}{l}\text { Current } \\
\text { system }\end{array}$} & \multicolumn{1}{l|}{ Difference } \\
\hline Flanders & 5.747 .184 .601 & -688.832 .191 & 5.058 .352 .409 & 5.113 .584 .644 & -55.232 .235 \\
\hline Wallonia & 2.492 .829 .684 & 521.565 .410 & 3.014 .395 .094 & 3.148 .167 .223 & -133.772 .129 \\
\hline Brussels & 737.705 .968 & 167.266 .781 & 904.972 .749 & 715.968 .385 & 189.004 .364 \\
\hline
\end{tabular}

Source: own calculations

\section{Policy implications and conclusions}

The results of this paper confirm that the current vertical equalization system in conjunction with the grant financing system, leads to a poverty trap for the Regions benefiting from equalization. Any economic catching-up that increases tax revenues in one of these Regions leads to a loss of revenues for the Regions.

The Belgian system of equalization grants should be re-designed to provide incentives to the recipient regions to develop their own revenue base. We follow the literature on fiscal federalism in suggesting a more fundamental reform. While the design of the equalization system matters, its interaction with other aspects of intergovernmental fiscal relations is relevant too. Some degree of tax sharing would allow the Regions to internalize the cost of their spending programs, thus generating stronger incentives for fiscal responsibility.

In this paper we discussed the incentive and budgetary effects of the replacement of the PIT transfer scheme by a PIT revenue sharing scheme and a horizontal equalization scheme based upon tax capacities. By eliminating the base tax-back problem the new scheme involves a win-win situation in the long-run for the Regions and the federal government. However, in the short run such a win-win situation is not possible. The current PIT grant to Brussels is far below tax capacity. The state reform of 2001 increased the fiscal autonomy (expressed as own tax revenues in terms of total revenues) of Brussels more than that of the other regions. The result was a stronger reduction of the PIT grant for Brussels. Hence a relatively low value of $\alpha$ guarantees the budgetary status-quo for Brussels. For Wallonia, on the contrary, the current PIT grant is far above tax capacity. A relatively high value of $\alpha$ is needed to guarantee the budgetary status-quo of Wallonia, but this status-quo is maintained at the expense of the 
budgetary status-quo of Flanders. A win-win situation for the Regions is always possible in the short run. Temporary additional grants from the federal government could guarantee that.

More fundamentally, the ex ante variation in regional tax revenues per capita could be reduced by making taxes such as the corporate income tax and property tax part of the financing scheme of the Regions. These taxes should also be integrated into the equalization scheme. The regions could also fund partially the communities from the proceeds of the personal income tax revenues. As the communities are responsible for initial schooling and hence future labour market opportunities, this would introduce some fiscal responsibility for these governments too.

Regarding the equalization scheme, the incentive effects of a Canadian style scheme are different from those under the German scheme. If the aim is to increase the tax bases, the Canadian scheme entails a win-win for all the regions involved.

Reforming Belgium's system of intergovernmental fiscal relations is a difficult task. But fundamental changes to Belgium's system of intergovernmental relations are called for to tackle the imbalances inherent to the current fiscal arrangements, which impede sustainable public finances.

\section{Bibliography}

Algoed, K. \& Heremans, D. (2008), The incentive effects of the Belgian Financial Arrangements For The Regions, working paper Steunpunt Fiscaliteit en Begroting (http://www.steunpuntfb.be/publicaties/A2_incentives_feb_08.PDF)

Boadway,R., The Theory and Practice of Equalization, CESifo Economic Studies, Vol. 50, 1/2004, 211-254

CATTOIR, P. and VERDONCK, M. (2002), Péréquation financière et fédéralisme, in CATTOIR, P., DE BRUYCKER, P., DUMONT, H., TULKENS, H. en WITTE, E., Autonomie, solidariteit en samenwerking, Larcier. 